\title{
Drosera BURMANNII: A CARNIVOROUS PLANT SPECIES FROM EASTERN GHATS OF INDIA
}

Soumen AdiTYA • M aju • H ow rah-711414 •W.B. • India • soumen_ad001@yahoo.co.in

The eastern G hats range of southwestern India, in the coastal part of A ndra Pradesh and O rissa state, is an area rich with diverse plants species. This area has a year-round subtropical climate with a temperature range between $15-25^{\circ} \mathrm{C}$ and heavy monsoonal rainfall.

While I was describing a new species (Caralluma moorei A ditya), I found a very red-colored D rosera burmannii Vahl, a well-known insectivorous sundew plant. The plants were growing on the eastern side of Panchlingeswar Hills - an area of open valley grassland. They were found in habitat associated with stony, gravel-rich, and very moist reddish alluvial soil (see Fig. 1).

The Panchlingeswar Hills are a part of the KuldihaW ildlife Sanctuary in the Balasore [B al eswar in Oria language] district of Orissa state. Plants from many diverse genera are found here, including Caralluma moorei, Caralluma diffusa, Sanseveria sp., Bombax malabaricum, Gyrocarpus americana, Euphorbia nerefolia, Ceropegia bulbosa var. bulbosa, many fern species, a few ground orchids, and Liliaceae sp.

At the time, I could not identify the Drosera plants, because the species flowers only in January and February, and I was too early. So I visited the area again in J anuary to see if I could find flowering plants. This time I found many plants with bud formation, two near to flowering, and one with a small seed pod. As I waited for a bit of sunshine, the plants showed pinkish flower buds, but did not fully open. I guessed that the plants might be D rosera burmannii, a deep red clone found in India. A ctually, this species is widely distributed from A ustralia, Japan, eastern A sia, and also subtropical India. The plants' color depends on sunshine - plants are more greenish under low light.

In cultivation, the plants grow quite well in my cool orchid house (see Fig. 2). I give them a soil mixture of one part sand, one part soil, and one and half part leaf mold with some added old bone meal. The soil is kept moist.

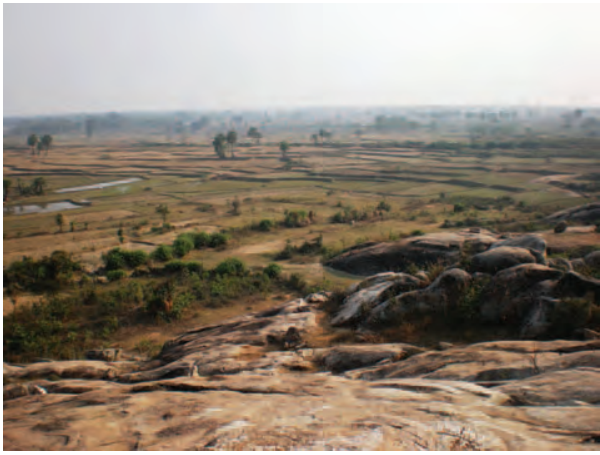

Figure 1: Panchlingeswar Hills, eastern Ghats Ranges.

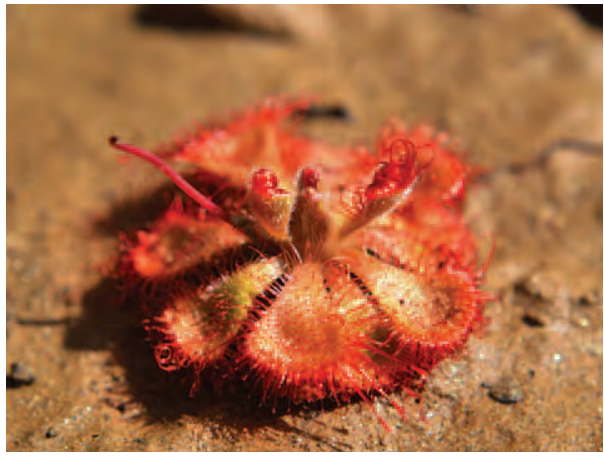

Figure 2: Drosera burmannii plants in cultivation.

\section{References}

J ain, S.K., and Sastry, A.R.K. 1980. Threatened Plants of India: A state-of-the-art report. B otanical Survey of India, Howrah. 23 p. 